\title{
O FRENÉTICO COMPASSO DA VALSA NEGRA: ASPECTOS DE VIOLÊNCIA CONTRA A MULHER NO ROMANCE DE PATRÍCIA MELO
}

\author{
ANA MARIA SOARES ZUKOSKI (UEM) ${ }^{1}$ \\ ANDRÉ EDUARDO TARDIVO (UEM) ${ }^{2}$ \\ WILMA DOS SANTOS COQUEIRO (UNESPAR) $)^{3}$
}

\begin{abstract}
RESUMO: O presente trabalho tem por objetivo apresentar uma análise interpretativa a respeito das particularidades da violência contra a mulher presentes no romance Valsa Negra (2003) de Patrícia Melo. Na obra, acompanhamos o narrador e protagonista em sua tentativa de controlar e objetificar sua nova esposa, Marie. Aos poucos, desnudam-se na obra inúmeros aspectos das mais variadas formas de violência contra a mulher: simbólica, doméstica e até mesmo física. Quanto mais inseguro o personagem se sente, maior o controle que tenta exercer sobre Marie, chegando a tomar medidas drásticas. À luz dos pressupostos teóricos da Crítica Feminista e dos Estudos de Gênero, abordados por pesquisadores/as como Bonnici (2007), Duarte (1997), Campos (1992), Muraro (1995), Nascimento, Gomes e Rebello (2009), discorremos sobre características do relacionamento abusivo que protagoniza a obra.
\end{abstract}

PALAVRAS-CHAVE: Crítica feminista. Relações abusivas. Masculinidade hegemônica.

ABSTRACT: The present work aims to present an interpretive analysis on the particularities of violence against women present in the novel Valsa Negra (2003), written by Patrícia Melo. In the novel, we accompany the narrator and protagonist in his attempt to control and objectify his new wife, Marie. Gradually, in the novel, reveals itself numerous aspects of the most varied forms of violence against women: symbolic, domestic and even physical. The more insecure the character feels, the more control he tries to exert over Marie, even taking drastic measures. In light of the theoretical assumptions of Feminist Criticism and Gender Studies, addressed by researchers as Bonnici (2007), Duarte (1997), Campos (1992), Muraro (1995), Nascimento, Gomes and Rebello (2009), we discuss characteristics of the abusive relationship that stars the work.

KEYWORDS: Feminist criticism. Abusive relationships. Hegemonic masculinity.

\section{CONSIDERAÇÕES INICIAIS}

Ao longo da história as relações entre homens e mulheres sempre foram pautadas na antinomia entre os sexos biológicos. Segundo Seabra; Muszkat "a experiência masculina da sexualidade é vivida como algo concreto e objetivo" (1985, p. 18) aludindo à presença do órgão sexual masculino que é visível em suas funções, contrariamente, a experiência feminina é "vivida através de fenômenos de natureza 'misteriosa'” (SEABRA; MUSKAT, 1985, p. 18), visto que o órgão sexual da mulher funciona de forma não visível, aludindo ao caráter misterioso sugerido pelas autoras. Aliando-se ao discurso religioso que, como se sabe, fundamentou padrões de comportamento em inúmeras sociedades ao redor do mundo, a figura feminina fora colocada como inferior e capaz de alcançar a plenitude apenas com a completude proposta pelo homem.

\footnotetext{
${ }^{1}$ Doutoranda pelo Programa de Pós-Graduação em Letras: Estudos Literários da Universidade Estadual de Maringá (UEM). Mestra em Letras: Estudos Literários pela mesma instituição. E-mail: anazukoski@gmail.com

2 Mestrando pelo Programa de Pós-Graduação em Letras: Estudos Literários da Universidade Estadual de Maringá (UEM). E-mail: tardivo.andre@gmail.com

${ }^{3}$ Doutora em Estudos Literários. Docente da Universidade Estadual do Paraná (UNESPAR/campus de Campo Mourão), atuando principalmente nos seguintes, temas: Literatura Brasileira Contemporânea, Literatura de Autoria feminina e Literatura e Ensino. E-mail: vilmacoqueiro@gmail.com
} 


\section{$=$ TRAMA $=$}

Ao reiterar a oposição biológica e social existente entre homens e mulheres, Freyre afirma que no patriarcalismo, "o homem faz da mulher uma criatura tão diferente dele quanto possível. Ele, o sexo forte, ela o fraco; ele o sexo nobre, ela o belo" (2000, p. 125). As diferenças entre homens e mulheres passam, então, a se distanciar cada vez mais, ancorando-se, também no discurso religioso, sobretudo o cristão, tornando-se natural a dissimilitude presente nas relações entre ambos. Todavia, adstrito a essa naturalização de papéis, inúmeros problemas potencializaram-se, nas palavras de Campos "a 'naturalização' de papéis sociais atribuídos aos sexos consolidou-se hierarquicamente, como se fosse da ordem do senso comum, quando, em verdade, neles se abrigam a dominação, a opressão, a exclusão" (1992, p. 113). O homem passa a controlar e a exercer seu poderio sobre a mulher, muitas vezes à base da violência, restringindo-a, unicamente, ao ambiente doméstico.

Therborn por sua vez, postula que as relações entre sexo e poder não são contraditórias, pois, "ambos são moedas conversíveis e mescláveis uma na outra" (2006, p. 11). Como se sabe, a família pode ser considerada a mais antiga instituição social; nela, as relações de poder e sexo são evidentes, haja vista que "estão inscritas nos direitos e obrigações dos membros" (THERBORN, 2006, p. 12) que dela fazem parte. Assim, ao homem cabe o dever de prover o sustento da casa e direcionar o comportamento familiar, tendo a esposa a obrigação de servi-lo e cuidar do lar e dos filhos. Isto posto, conforme nos ensina Muraro (1995), aos homens fora concedido o domínio público, ou seja, as relações exteriores ao ambiente doméstico, ao passo que às mulheres, fora alocado o domínio privado, cujas tarefas consistem nas atividades internas à casa e à reprodução.

\section{SEXO, PODER, VIOLÊNCIAS E MEDO: O SOTURNO MUNDO DAS MULHERES}

O homem, desde os primórdios da Antiguidade, em razão da força de que dispunha aliada aos mecanismos regulatórios de dominação, tal como a Igreja, sempre esteve no ápice das relações sociais, as quais, não raras vezes, foram alcançadas por meio do uso da violência. Nascimento, Gomes e Rebello afirmam que "a legitimação do domínio do masculino sobre o feminino dentro da ideologia de supremacia pode ocorrer por meio do uso da violência, outorgando aos homens [...] o direito de usá-la" (2009, n. p.). Durante muito tempo e ainda hoje, em algumas sociedades, o homem possuía o direito legal de castigar fisicamente sua mulher. Bonnici afirma que:

Nas culturas patriarcais, da Antiguidade até o Renascimento, o marido tinha o direito de punir fisicamente sua mulher, por palavra ou pancadaria, conforme o ditado de Santo Agostinho. Nas culturas não-ocidentais, especialmente na China, na África e no Oriente Médio, bater na mulher era uma prática comum (2007, p. 263-4)

Corroborando a afirmação de Ritt, Cagliari e Costa, "na América colonial, mesmo após a independência americana, a legislação não só protegia o marido que 'disciplinasse' a sua mulher com o uso de castigos físicos, como dava a ele, expressamente, esse direito" (2009, n. p.). Há que se ressaltar, todavia, que às mulheres eram impingidos, também, outros tipos de violências, como, por exemplo, psicológicas, sexual e moral, entre outras formas de rebaixamento. Embora, com o passar dos anos, políticas públicas tenham minimizado a violência contra a mulher no Brasil, sobretudo após o advento da Lei Maria da Penha, promulgada em 2006, muitas mulheres ainda padecem nas mãos de seus maridos ou companheiros sofrendo das mazelas de um constructo social que insiste em relegar a figura feminina a níveis inferiores de poder, conhecimento e autonomia. 


\section{$=$ TRAMA $=$}

De acordo com Tiburi, uma das reivindicações basilares das mulheres contemporâneas diz respeito à violência doméstica. Segundo a autora "a desigualdade do trabalho doméstico, o papel da maternidade e toda uma lógica do próprio casamento como submissão da mulher ao homem têm muito de um tipo de violência, que é a simbólica" (2018, p. 106). Salienta-se que, em um país da proporção do Brasil, cuja população feminina corresponde a $51,03 \%{ }^{4}$, ainda tenhamos tantas mulheres preteridas dos cargos de poder e incapazes de contribuir para as decisões que podem mudar o futuro da nação, ficando, assim, reclusas a tarefas domésticas e de suporte para o êxito masculino. Percebe-se, então, que mesmo na contemporaneidade as mulheres permanecem enredadas pelo patriarcalismo ainda que de forma velada. Tiburi destaca que as mulheres ocupam maior destaque no que diz respeito ao mundo da violência em detrimento ao do poder, e que é curioso que mesmo a população feminina sendo superior à masculina, ainda tenhamos tão poucas mulheres ocupando cargos políticos de destaque. Em síntese, segundo a crítica, "enquanto a violência é 'sofrida' por mulheres, o poder é 'exercido' pelos homens” (2018, p. 107).

\section{LITERATURA E MULHERES: MEDO, CORAGEM E O DESANUVIAR DE UM NOVO TEMPO}

As relações de poder que sempre permearam e que, em certa medida, ainda se entrepõem na dicotomia homem e mulher, evidentemente tornam-se presentes nas mais variadas formas de arte, como a literatura, por exemplo. Durante muito tempo as mulheres ficaram totalmente banidas do cenário literário, primeiro no que tangia à leitura de obras, posto que as atividades intelectuais se restringiam ao círculo social masculino. Subsequentemente, após conquistarem o direito à leitura, a elas eram destinados exclusivamente romances denominados "cor de rosa", isto é, histórias que as impelissem à busca pelo marido e pelo sucesso no ambiente doméstico. Algumas mulheres, na tentativa de inserir-se na seara literária predominantemente masculina, recorreram a pseudônimos e, assim, "superaram os obstáculos escrevendo e publicando, num flagrante desafio à ordem que as restringia à esfera privada" (DUARTE, 1997, p. 57). Outras, submissas aos pais, irmãos e maridos, foram silenciadas pela tradição canônica vigente que as propeliam ao esquecimento.

Com os avanços das conquistas feministas do século passado, as mulheres passaram a ter mais voz e os estudos sobre a produção literária feminina de séculos findados tornaramse recorrentes. Showalter apud Zolin (2009) propõe três fases para explicitar a escrita das mulheres, quais sejam: feminina, feminista e fêmea que correspondem, respectivamente, à reprodução dos valores patriarcais vigentes, à denúncia da condição sociocultural da mulher e, finalmente, à autodescoberta.

A literatura contemporânea feminina proporciona discussões e reflexões sobre o papel da mulher em sociedade, oportunizando debates não apenas sobre a representação feminina, mas apresentando-se também como forma de denúncia para as várias formas de violência às quais as mulheres encontram-se submetidas, sobretudo diante de um cenário que cada dia se torna mais alarmante, visto a maximização acelerada dos casos de feminicídio. Nesse sentido, podemos destacar os romances A chave de casa (2003), de Tatiana Salem Levy; Sinfonia em Branco (2001), de Adriana Lisboa; Um deus dentro dele um diabo dentro de mim (2003), de Nilza Rezende; Garotas Mortas (2018), de Selva Almada; e Valsa Negra (2003), de Patrícia Melo, os quais proporcionam ao leitor um fiel retrato das violências física e psicológica às quais as mulheres estão vulneráveis.

\footnotetext{
${ }^{4}$ Dados da distribuição da população por sexo de acordo com o IBGE, censo do ano 2010. Disponível em <
} https://brasilemsintese.ibge.gov.br/populacao/distribuicao-da-populacao-por-sexo.html> acesso em jan. 2019. 


\section{$=$ TRAMA $=$}

Melo é reconhecidamente um dos expoentes da literatura policial brasileira ocupando um papel de destaque em um nicho predominantemente masculino, tendo como precursor do romance policial no Brasil Rubem Fonseca, e, no que concerne à literatura mundial, torna-se impossível problematizar o gênero sem trazer à baila o inglês Arthur Conan Doyle com o seu inesquecível Sherlock Holmes. Embora a crítica especializada insista em relegar a produção literária feminina, mormente no que tange ao gênero policial, Patrícia Melo destaca-se neste cenário, possuindo obras premiadas, como Inferno (2000) e Ladrão de cadáveres (2010), além de seus romances se tornarem objeto de estudo no âmbito acadêmico.

Em Valsa Negra, nos é apresentada a história de um renomado maestro que abandona a esposa e a filha para relacionar-se com Marie, uma violinista judia de sua orquestra e trinta anos mais nova. Com um narrador autodiegético, o romance, cujo título alude à "Valsa da dor", de Villa-Lobos, conduz o leitor para um exame minucioso da psique desse maestro que objetifica o relacionamento e acaba por sucumbir ao ciúme doentio que sente. O presente trabalho tenciona suscitar discussões acerca das várias formas de violência presentes no romance de Patrícia Melo, deslindando o perverso mundo de medo e opressão ao qual muitas mulheres estão submetidas no próprio lar.

\section{PODER, MEDO E VIOLÊNCIA: A ANTINOMIA HOMEM X MULHER NAS RELAÇÕES DOMÉSTICAS}

No romance corpus deste trabalho, diversas personagens femininas transitam e apresentam particularidades distintas da mulher contemporânea, todavia, nos atentaremos apenas para os tipos de violências impingidos. Como mencionado, a violinista relaciona-se com o maestro enquanto ele era casado com Teresa, fato este que culmina no divórcio e posterior casamento com a jovem judia. Enquanto moram juntos, Marie começa a sofrer as agruras do relacionamento, visto que o marido passa a vigiá-la e a desconfiar de que ela o está traindo com os membros da orquestra. O comportamento do homem opressor começa a se mostrar anormal, invariavelmente, por pequenos pensamentos que, a princípio, para ele, soam como normais, devido à naturalização e romantização do ciúme pela sociedade. Assim, gestos como mexer nos pertences da companheira e observar os passos da mulher, por exemplo, não parecem anômalos, todavia, esses são os primeiros sintomas de que o relacionamento pode estar fadado ao fracasso:

Para mim, no entanto, quebrar as pernas seria o pretexto ideal para pôr em prática meus planos em relação a Marie. Viajar menos, cancelar os concertos de Ottawa e Palermo, não trabalhar e ficar em casa, observar minha mulher, checar, vigiar seus passos. Manter-me alerta e evitar a catástrofe. É assim que um homem age de verdade (MELO, 2010, p. 13).

O maestro deseja ficar em casa unicamente para poder vigiar os passos da esposa, pois acredita que ela poderá traí-lo a qualquer momento e cabe a ele, o homem, evitar tais acontecimentos, ratificando o ideário que concerne ao homem o controle e a manutenção matrimonial. O comportamento masculino obsessivo aliado à falta de acompanhamento médico, entre outros fatores, potencializa os crimes de feminicídio mundo afora, de modo que o homem não é capaz de enxergar suas faltas e seu comportamento criminoso. A violência contra a mulher, em um relacionamento heterossexual, possui diversas particularidades que vão "desde o xingamento até a circuncisão feminina e o assassinato" (BONNICl, 2007, p. 260). O fato de a mulher usar roupas curtas e/ou justas já cria no imaginário masculino o desejo, por parte da mulher, em se exibir para outros homens e, assim, de cometer o adultério. Destarte, 


\section{$=$ TRAMA $=$}

apenas insultá-la moralmente não é suficiente, é preciso criticar, também, a maneira como se veste:

Queria que Marie se fodesse, que não tivesse nada além de mim, nem música, nem dinheiro, nem violino, nem Sandorsky, nada. E que não usasse aquela blusa exibicionista. Como não podia dizer isso a ela, disse outras coisas, também horríveis (MELO, 2010, p. 34, grifos nossos).

$[\ldots]$

Marie já estava terrivelmente ofendida, mas eu desejava magoá-la mais ainda. Não foi difícil fazer o insulto final.

'E ponha uma roupa menos provocadora para ensaiar', eu disse. 'Assim, quem sabe o Rodrigo consegue virar a página'” (MELO, 2010, p. 35, grifos nossos).

A crítica que o narrador e protagonista faz às roupas de sua esposa na realidade revelam o desejo indiscriminado por controle, isto é, ela só deverá usar as roupas que passarem pelo crivo de aprovação dele. Essa ânsia pelo controle do relacionamento e de sua parceira faz com o que o homem tome atitudes nefastas, como, por exemplo, a ambição à exclusividade da vida de Marie. Nada que a mulher faça desperta no homem o companheirismo esperado numa relação a dois; pelo contrário, o desejo obsessivo do maestro, além de propiciar o seu deleite durante as provocações, faz com que deseje que a esposa sofra todas as perdas possíveis e imagináveis, tanto no plano sentimental quanto no material, pois tenciona que Marie direcione a ele todas as suas atividades, assim como a sua própria vida, ou seja, que ela se torne totalmente dependente dele.

O ciúme do narrador vai para além da traição imaginária que alimenta. O sentimento atinge proporções dogmáticas quando, movido pela raiva da relação de Marie com sua religião, suborna a empregada da família, Jânia, para que esta jogue fora toda a coleção de jornais da violinista e para que anote todos os seus passos: "'Anote o nome de quem vem aqui', eu disse, 'e das pessoas com quem ela fala ao telefone'. Expliquei que também deveria ouvir, pela extensão da cozinha, as conversas telefônicas de minha mulher" (MELO, 2010, p. 21). É perceptível que, não estando contente em vigiá-la, é necessário que outras pessoas o ajudem a mantê-la sob observação, além de que, qualquer atividade que não esteja ligada a ele soe como afronta, até mesmo os momentos felizes da vida anterior ao casamento da personagem eram desconfortáveis para ele:

Demorou algum tempo para eu entender o que se passava comigo. Eu. Eu não estava ali. Era isso que via, a minha ausência. Eu não suportava não estar ali. Não pertencer. Não fazer parte. Estar atrás. Estar depois. Não estar. Aquilo me atingia, como um golpe (MELO, 2010, pp. 70-71).

Ao cercear os passos da companheira, o maestro não sente confiança, pelo contrário, aumenta sua suspeição e começa a intentar outras maneiras de controlá-la. A sua insegurança o impele a aumentar o controle que tenta exercer sobre a vida da esposa para que ele passe a ser o centro: "Ocorreu-me então que Marie poderia fazer com as matérias a meu respeito o mesmo que fazia com os artigos sobre Israel. Recortá-las, guardá-las, lê-las com atenção. Fiquei contrariado ao pensar que ela nem sequer me vira no jornal." (MELO, 2010, p. 24). A irritação que atinge o personagem diz respeito ao fato de não ser ele o objeto de atenção de Marie no que tange aos recortes de jornais. Nesses, Marie busca notícias sobre Israel e as questões judias, que compõem sua origem e demonstram a vontade da personagem em encontrar-se nas suas identidades. Até mesmo desse fato, o narrador sente-se enciumado, devido não ser judeu e não ocupar a posição que o judaísmo ocupa na vida da mulher. 


\section{$=$ TRAMA $=$}

O narrador tem consciência de seu comportamento, todavia acredita que as tensões que provoca no relacionamento devem ser resolvidas, sempre, na cama. "Brigávamos muito por causa dessas coisas todas, havia muitos desentendimentos, muito sentimento de posse, da minha parte, muita desconfiança, exigências, mas invariavelmente nossa tensão se resolvia na cama." (MELO, 2010, p. 50). Tal sentimento de posse que o personagem narrador afirma possuir, aos poucos vai evoluindo até tomar proporções assustadoras, a ponto de tentar objetificar a esposa. De acordo com Bonnici (2007, p. 192), a objetificação é um modo pelo qual um grupo ou o indivíduo é tratado pelos demais como objeto. Concebe-se como uma prática característica da ideologia patriarcal e colonial, em designar o outro, que se diferencia por meio da religião, raça, etnia, ou gênero, como inferior. Para demonstrar como Marie era inferior a ele, o protagonista vale-se do âmbito profissional, para subjugar e the impingir a humilhação:

\footnotetext{
"Não é possível, Marie, que, neste trecho, você olhe para a parte. É para mim que tem que olhar. Olha para a minha batuta, porra. Tem que saber este trecho de cor. Esse é o único trecho que você tem que saber de cor."

Marie se levantou.

"Senta", gritei.

Não olhei mais para ela. Segui em frente, regendo com raiva. Desconsiderei seu ar indignado, seu sentimento de humilhação, a perda de andamento, o desencontro rítmico (MELO, 2010, p. 31).
}

O maestro atribui toda a sua frustação por não conseguir controlar a roupa da esposa, punindo-a no serviço, descontando sua fúria ao desqualificá-la como profissional. Ao afirmar que é para ele que ela deve olhar, é compreensível que isso não se aplique apenas pelo fato dele ser o maestro que rege o concerto, mas que isso transgrida a barreira profissional, e que é apenas para ele que ela deve dirigir o seu olhar, independentemente do local e da situação. Percebe-se que os homens procuram exercer sobre as mulheres o domínio exacerbado, de forma que elas não conseguem sair das amarras de relacionamentos tão perturbadores. Para tanto, os homens valem-se de todo ideário construído em seu derredor aliado à força física e ao modo como a sociedade, infelizmente, enxerga a mulher. Diante de todo esse cenário, os homens sentem-se confortáveis e detentores do direito de agir dessa maneira, humilhando e rebaixando as mulheres ao nível da objetificação. Ao desconsiderar o sentimento de humilhação ao qual Marie vê-se submetida por ele, evidenciam-se alguns aspectos do relacionamento abusivo e apontam para a presença da violência doméstica, que pode ser concebida como "uma forma de violência física e/ou psíquica, exercida pelos homens contra as mulheres, no âmbito das relações de intimidade e manifestando um poder de posse de caráter patriarcal" (SABADELL, 2003, p. 235-236). Outra atitude do narrador que tipifica o relacionamento como abusivo é o fato de ele atribuir a culpa de seu descontrole a Marie:

O tempo todo Marie me incitava a ter esse tipo de comportamento. Gostava de me incendiar, insinuava, lançava nas nossas conversas, sempre de forma que parecesse casual, nomes como Jean-Pierre, David ou Henrique, rapazes com quem havia estudado, 'não tive nada com eles', ela me dizia, enquanto eu ardia no inferno (MELO, 2010, p. 17).

A simples menção de nomes masculinos, causava imenso desconforto no personagem, que na sua visão, pertencia ao jogo que Marie fazia com ele, para que manifestasse esse comportamento agressivo e controlador. Mesmo afirmando não ter estabelecido nenhum tipo de vínculo ou de relacionamento com os rapazes, isso não é 


\section{$=$ TRAMA $=$}

suficiente para acalmar a mente controladora do maestro, que se utiliza da metáfora do inferno, para descrever sua situação enquanto esposo de uma mulher trinta anos mais jovem que ele, além de denotar a insegurança do narrador referente a si mesmo.

Apesar de ser altamente exigente com seus músicos, no que concerne a horários e compromissos assumidos, o maestro não demonstra possuir a mesma postura quando se refere a Marie, ainda que ela faça parte do concerto, como violinista. Na sua concepção, não é à orquestra que ela devia sempre estar disponível, mas sim para ele. Isso reflete-se quando ela, devido a compromissos assumidos na orquestra, recusa-se viajar com ele, para acompanhá-lo em concertos que regerá na Europa:

\footnotetext{
"Peça demissão", sugeri, exasperado. Ela e Cláudio, riram, como se eu estivesse brincando. Eu mesmo ri e fingi que não era sério. Mas fiquei desapontado com isso, perdi a vontade de reger na Europa. Não sei o que me incomodou mais, se foi a ideia de viajar sozinho, aquela chatice de avião e aeroporto, ou se foi perceber a independência de Marie (MELO, 2010, p. 62).
}

Ante a postura de Marie e Cláudio que não consideraram seriamente a proposta dele em fazer sua própria esposa pedir demissão para segui-lo em um compromisso de carreira, o maestro acabar por fingir que de fato estava brincando. Mas isso não reflete em sua postura que, assim como uma criança mimada contrariada, perde a vontade de seguir sua carreira, que consequentemente depende dessas turnês pela Europa. Ele encontra-se preso a essa necessidade de controlar a esposa, resumindo a sua vida em vigiar e fiscalizar as ações de Marie, que não se submete totalmente a ele.

É evidente no excerto, que na realidade o maior incômodo para o maestro não é aquela "chatice de avião e aeroporto" mas sim a "independência de Marie", ou seja, a percepção de que o controle que ele tenta exercer sobre ela está sendo uma atividade em vão. Isso é corroborado pela irritação que ele sente quando a violinista afirma a sua individualidade: "Nem que repetisse com tanto entusiasmo palavras como 'meu violino', 'minha carreira', 'meu futuro', 'meus projetos'” (MELO, 2010, p. 64). A ênfase no uso do pronome 'meu' incomoda o maestro pelo fato dele não estar incluído na vida dela, como ele acredita que deveria estar.

O relacionamento de ambos encaminha-se cada vez mais para os aspectos que o caracterizam como abusivo, uma vez que não era Marie que mais importava para ele, mas sim o controle e sujeição dela para com ele: "Nem Marie escapava dessa fúria. Se não estávamos enlaçados um ao outro, se ela não estava me adorando, meus sentimentos em relação a ela eram bastante ambíguos" (MELO, 2010, p. 70). O narrador sente a necessidade de ser o centro da vida, não apenas dele, mas também de sua companheira, sufocando-a então e a impedindo de ser protagonista de sua vida. Os sentimentos ambíguos assinalam essa questão, ou seja, o relacionamento, para o maestro, não era pautado em sentimentos como amor e companheirismo, mas sim como adoração e devoção, além da submissão.

Um fator que chama a atenção nos relacionamentos abusivos diz respeito aos ciúmes exacerbados que os homens têm de suas esposas/companheiras, contudo, há que se ressaltar que não se trata do medo de ser traído ou deixado apenas, mas sim de uma possível ausência de posse. Há diversas formas de tratamento médico que, se não curam ao menos minimizam os danos causados e, quem sabe, permitem a continuidade do relacionamento. Todavia, os homens apresentam certa resistência em procurar ajuda médica, pois acreditam, primeiramente, que não há problemas a serem resolvidos, e também por não aceitar expor suas patologias.

Outro problema encontrado nessas situações concerne aos efeitos colaterais que a medicação prescrita produz: "À noite, joguei fora todos os remédios. Liguei para Homero e disse 


\section{$=$ TRAMA $=$}

que não queria mais aquela porcaria. Já não conseguia nem trepar por causa deles. Meu pau simplesmente não ficava duro" (MELO, 2010, p. 125). A prioridade para o maestro são as questões sexuais e corporais, demonstrando que não reconhece que seu ciúme extrapola o limite da individualidade do outro e não se preocupa em resolver tal questão. Não está disposto a renunciar ao sexo pela sanidade mental.

Desacreditado da medicina, o narrador deixa de tomar os medicamentos por sua própria conta e fica vibrante ao verificar que voltava a ser sexualmente ativo: "Fui até o banheiro e fiquei alguns minutos me observando, eufórico, como era bom ter meu pau duro de volta. $\mathrm{O}$ que é, afinal, um homem sem isso? Para que servem a memória e o talento, se o nosso pau não sobe?" (MELO, 2010, pp. 130-131). A associação do talento ao ato de transar, nesse contexto, soa de forma extremamente machista, pois na visão do personagem, as mulheres se interessam sexualmente apenas por homens bem sucedidos, reforçando um estereótipo de interesseiras a elas. Ao questionar-se sobre o que é um homem sem um pênis ereto, percebemos o quão pequena e machista é a ótica do protagonista, que resume o homem a um membro: o falo. Considerando o contexto e o desmembramento da cultura patriarcal, assentada sobretudo na imagem do falo como sendo superior e representando a falta na mulher, é contundente que o narrador enfatize tanto esse membro. Tal postura é coerente com as atitudes dele, sendo manipulador e controlador, por acreditar ser superior a sua esposa. Não obstante, à mulher caberia a associação entre sexo e amor, enquanto aos homens, como o próprio narrador afirma: "Colocar sexo e amor num único pacote deve ser uma patologia feminina. Nós, os macacos, não associamos sexo a nada. Sexo é sexo" (MELO, 2010, p. 150). Este posicionamento reitera o posicionamento de Freyre ao afirmar: "O homem patriarcal se roça pela mulher macia, frágil, fingindo adorá-la, mas na verdade para sentir-se mais sexo forte, sexo nobre, mais sexo dominador" (2000, p. 130).

A recusa em seguir com o tratamento que iniciara por sugestão da esposa impele o maestro para uma espécie de obsessão: "Eu ainda tinha outro concerto em Nápoles. Antes das sete, já estava de banho tomado, resolvendo tudo por telefone. Falei com meu agente em Londres, não foi difícil arranjar um maestro substituto" (MELO, 2010, p. 88). Mesmo já estando fora do Brasil, a necessidade de controlar Marie, que havia se recusado a acompanhá-lo, tornase tão grande a ponto de cancelar os demais concertos e voltar para o país a fim de verificar se não estava sendo traído. A obsessão atinge um grau exacerbado e o impele a prejudicar sua própria carreira para manter o controle sobre sua esposa. O cancelamento de um evento internacional evidencia a que ponto o maestro chegara na sua crença de superioridade à esposa. Na realidade, isso demonstra como ele já havia perdido o controle de suas ações.

Durante toda a viagem de volta, que não foi avisada para Marie, o maestro focalizava seus pensamentos em apenas uma coisa: a esposa o estava traindo, apesar de na obra, mesmo com a focalização do narrador autodiegético, não existir evidências concretas de que Marie possuísse qualquer tipo de relacionamento com outros homens. Isso demonstrava ser apenas fruto da imaginação do narrador que não podia ficar muito tempo com a mente livre que já começava a formular tais desconfianças. A insegurança que essas dúvidas provocavam acabavam por revelar o lado mais violento do maestro: "Traição. Antes perder, pensei. Imaginála morta foi menos doloroso. É curioso como as ideias se formam na cabeça dos homens. Eu sempre pensava nisso quando lia notícias horriveis nos jornais" (MELO, 2010, pp. 92-93). É palpável o nível que o ciúme obsessivo atingiu nesse personagem, preferindo ver a mulher que diz amar morta que com outro homem ou longe de seu domínio. Não demonstra possuir remorso por pensar dessa maneira, contrariamente, atribui características como 'curioso' à forma de pensar, que na sua visão é comum se formar nas cabeças masculinas. 


\section{$=$ TRAMA $=$}

A insanidade que toma o maestro manifesta-se em suas atitudes quando chega de volta ao apartamento que habita junto com a esposa: "Acendi as luzes e comecei a vasculhar o quarto. Marie levantou-se num sobressalto, sem entender o que acontecia. 'Onde está?', eu perguntava, enquanto revirava armários, gavetas e jogava tudo no chão" (MELO, 2010, p. 96). A fúria dirigida inicialmente aos objetos, como os armários e gavetas, não demora a ser transferida para a esposa: "Depois, Marie contou-me que eu a peguei pelos cabelos e fiz com que ela se agachasse no chão e olhasse comigo embaixo da cama. Não me recordo de ter feito isso. Mas me lembro de ter apontado a faca para ela" (MELO, 2010, p. 98). O nível de agressividade atinge a violência física, quando ele a agarra pelos cabelos, bem como quando ele a ameaça com a faca. Esse momento crítico possibilita a caracterização completa desse relacionamento abusivo. A insegurança masculina aliada à incapacidade de controlar totalmente a esposa, fazem com que o maestro revele um lado totalmente desiquilibrado e agressivo, que não compreende a mulher como parceira, mas sim como produto sob sua posse.

Como é característico dos relacionamentos abusivos, a vítima tende a perdoar o agressor inúmeras vezes, e com o casal de Valsa Negra não foi diferente: "Ficamos totalmente em paz, eu e Marie. Não falamos sobre o que ocorreu, a faca, meu ciúme, o violino despedaçado. Foi como se nada tivesse acontecido." (MELO, 2010, p. 104). Não abordar o acontecido não isenta nem representa uma mudança por parte do maestro que demonstra recordar-se bem do acontecido. A violência praticada, em sua ótica, transforma-se em ciúme, mesmo colocando 'faca' e 'violino despedaçado' na mesma frase. O ciúme é utilizado para justificar as atrocidades cometidas por ele, mas não há reflexões sobre o sobrepujamento dos limites, nem mesmo sentimentos como culpa ou arrependimento.

Outro fator que elucida o comportamento machista do protagonista reside no fato dele ter traído a primeira esposa, Teresa, para se casar com Marie e, não satisfeito, durante as crises com a violinista, mantém um caso extraconjugal com sua secretária. As atitudes do maestro refletem sua forma de pensar:

Depois de duas doses de uísque, apresentou uma teoria bastante científica sobre a tendência biológica do ser humano à traição, que lera numa dessas revistas semanais. 'Pau duro significa bombeamento de sangue. Até para trair, o macho trabalha mais. Já as mulheres não precisam de nada. Abrem as pernas e pronto, assunto resolvido.' Para ele, a ideia da fidelidade era 'uma falácia catalogada'. 'Os cientistas afirmam que até os piolhos traem' (MELO, 2010, p. 129).

Assim, o personagem reduz a mulher a um agente passivo durante a relação sexual, pois a ela, como bem evidenciado no fragmento acima, caberia apenas satisfazer os desejos do homem. Por outro lado, deixa evidente que as mulheres também traem, apresentando ao mesmo tempo um comportamento machista, uma vez que as reduz ao objeto receptor da traição, mas também destacando que a traição faz parte do ser humano e não uma exclusividade masculina, como uma forma de isentar a negatividade de sua conduta.

As atitudes do maestro seguem sendo invasivas e desrespeitosas no que tange à individualidade da esposa: "Depois do ensaio da tarde, cancelei meus compromissos e, quando Marie deixou a garagem da orquestra, já estava no carro, pronto para segui-la" (MELO, 2010, p. 133). É visível como o narrador acaba por reduzir a sua vida a controlar a da esposa. Para ele, é preferível seguir de carro os passos de sua mulher do que cumprir os compromissos assumidos em sua orquestra. O comportamento de seguir e vigiar Marie reflete que o marido deseja retirar dela o seu direito assegurado constitucionalmente de ir e vir, pois assim ficaria mais fácil controlá-la. A invasão da privacidade da esposa alcança também o nível do celular, quase diariamente examinado: 


\section{$=$ TRAMA $=$}

Chequei o celular de Marie, anotei os números registrados nas 'chamadas recebidas'. Liguei para cada um deles, procurando pistas. Confrontei as informações que ela me passava. Telefonei para o dentista, perguntei se ela havia estado lá. Fiz o mesmo com o cabeleireiro, onde ela disse ter cortado o cabelo, muito embora eu não conseguisse ver o tal corte (MELO, 2010, p. 135).

Não bastasse invadir a privacidade da companheira, o maestro age de forma descontrolada ao prendê-la, em seus acessos de fúria em sua sala interrogando-a sobre histórias antigas na tentativa de encontrar divergências nas versões apresentadas. Nesses momentos de descontrole, o narrador não se sente desconfortável em agir de maneira despudorada, pelo contrário, acredita que tais ações fazem parte do que é, de fato, ser um homem de verdade, o que inclui: "examinar sua bolsa, abrir sua correspondência e conferir recibos e contas telefônicas" (MELO, 2010, pp. 157-8).

Mesmo sentindo-se desconfortável ante o comportamento dissimulado e agressivo do marido, Marie sempre dava segundas chances ao companheiro, representando de forma adequada o comportamento de mulheres submissas e inseguras quanto a uma vida longe dos parceiros, bastava que ele dissesse: “'Tudo bem', eu disse. 'Acabou. Eu mudei. Prometo'” (MELO, 2010, p. 154), para que ela o aceitasse de volta. Todavia, diante de fatos tão calamitosos como a invasão de suas correspondências e as perseguições de carro, Marie começa a se sentir amedrontada. Após a descoberta do suborno da empregada para que a vigie, Marie coloca o marido contra a parede e ele, mais uma vez, mostra-se dissimulado e cínico: "Não era verdade que eu pagara nossa empregada para espiar Marie. Eu simplesmente dava dinheiro a ela e cansei de ouvir seus agradecimentos" (MELO, 2010, p. 140). É explícito que o maestro usa todas as situações possíveis para pôr em evidência suas qualidades, entretanto, essa necessidade de autoafirmação mostra na realidade o quão hipócrita ele é ao tentar eximir-se de suas lamentáveis atitudes impulsionando à situação econômica e social de Jânia o seu mau caratismo.

Muitas mulheres, infelizmente, não têm tempo suficiente para enxergar as mazelas de um relacionamento abusivo, não raras as vezes, acabam mortas por seus companheiros que, durante todo o relacionamento, afirmavam amá-las. No romance corpus deste trabalho, todavia, Marie decide pôr um basta na relação e busca ajuda junto aos pais, contudo, o maestro, como a maioria dos homens que cometem todos os tipos de violência contra as mulheres, não desiste tão fácil: "Ficava lá, de tocaia, aguardando Marie sair. No início, queria apenas vê-la. Depois, passei a segui-la, anotar os lugares onde ela almoçava ou fazia compras. E também tentei abordá-la, algumas vezes" (MELO, 2010, p. 163).

Nessas situações, os homens chegam a cometer as maiores loucuras para manteremse no controle de suas esposas, sobretudo quando essas resolvem colocar um basta na série de abusos do relacionamento. No caso do maestro, este põe de lado toda a sua vida profissional, deixando de comparecer aos ensaios, desmarcando compromissos previamente agendados e faltando ainda mais enquanto pai, de modo que desconta na filha todo o seu ódio pelo fim do relacionamento com Marie. O narrador cogita, inclusive, a se mudar para perto da casa de Monique e Henri, os pais de Marie, para que possa dominar de forma mais veemente possível a vida da companheira: "Fui tomado pela ideia de morar naquele local. Dali, poderia vigiar constantemente Marie, acompanhar todos os seus movimentos com relativa facilidade" (MELO, 2010, p. 173).

O medo sentido pelas mulheres vai muito além das invasões de privacidade que situações como a retratada no romance evidenciam, elas temem por suas próprias vidas: "'Tenho medo de você', ela falou. 'Cada vez que você se aproxima, fico apavorada"' (MELO, 2010, p. 191). Por outro lado, os homens acreditam que seu comportamento é normal, pois 


\section{$=$ TRAMA $=$}

precisam manter suas mulheres sob seu domínio, uma vez que, historicamente, ratificado pelo discurso religioso, caberia à mulher submeter-se ao marido: "a paixão vai arrastar você para o marido, e ele a dominará" (Gênese [3:16], A BÍBLIA, 1997, p. 17).

Destaca-se que o medo sentido e expressado pelas mulheres nessas situações não atenua em nada o comportamento masculino; de maneira oposta maximiza as atitudes do parceiro que se sente mais poderoso e, como no caso do protagonista do romance, aumenta as agressões:

\footnotetext{
“Você não percebe que acabou?", ela disse, certa vez. "O que eu devo fazer para você entender isso?" Sim, eu compreendia cada palavra, mas ela não poderia voltar para mim? Não poderia me perdoar?

$[\ldots]$

Nosso último encontro fora lamentável, depois de persegui-la pelas ruas dos Jardins, emparelhei meu carro ao dela no farol, desci e comecei a dizer que ela jamais tivera aula com Sandorsky, que os dois foram amantes e que eu sabia de tudo (MELO, 2010, p. 164).
}

Não raras as vezes as violências sofridas contra as mulheres acabam em crimes contra a vida da pessoa humana, seja o autor da violência, seja o agente passivo do delito, comumente a morte se faz presente nestes relacionamentos. Muitos sujeitos, diante do rompimento com seus/suas companheiros/as, decidem dar fim à própria vida, pois não encontram mais motivos para viver. Embora o suicídio seja visto de forma inesperada para os familiares das vítimas, elas geralmente dão pistas do que têm em mente, muitas vezes chegando a verbalizar o desejo da morte, como é o caso do protagonista: "Marie subiu as escadas, fui atrás e, quando ela bateu a porta do quarto no meu rosto, comecei a gritar, disse que daria um tiro na cabeça se ela não voltasse a viver comigo" (MELO, 2010, p. 193). No tocante ao personagem em questão, há que se ressaltar que tais pensamentos sobre dar fim à própria vida não vêm desprovidos do desejo de eliminar suas parceiras, tanto é que, quando do relacionamento com a primeira esposa, afirma: "[...] pensando que houve um tempo em que eu gostava tanto de Teresa, tinha tanto carinho por ela, que chegara a pensar em matá-la, só para não lhe dar o desgosto da separação" (MELO, 2010, p. 143). Percebe-se que, ao ser posto contra a parede por suas atitudes no relacionamento e pelo adultério, o maestro mostra-se descontrolado e cogita a ideia de eliminar a esposa como forma de excluir, também, os problemas que dela porventura surgiriam: "gastei dias pensando numa boa forma de matar Teresa. Jamais quis que Teresa sofresse, jamais" (MELO, 2010, p. 143).

O relacionamento com Teresa demonstra ter chegado ao fim em função das diversas falhas cometidas pelo regente da orquestra aliadas ao adultério. Todavia, durante seu primeiro casamento, o relacionamento com a filha, Eduarda, já não era saudável. Sobre as crianças, o maestro afirma:

\footnotetext{
Jamais gostei de crianças, essa é a verdade. Sempre me espantei com a rapidez com que aprendem a mentir, a enganar, a ser hipócritas e egoístas, e a velocidade com que se transformam nuns cretinos adultos, como todos nós. Além disso, as crianças nascem e acabam os casamentos. Realizam a mulher, nunca o homem (MELO, 2010, p. 80).
}

Fica nítida a forma como o personagem encara as relações conjugais: ao homem o papel provedor, sexual e detentor do poder, à mulher a realização com a maternidade e o ambiente doméstico. Sobre essas relações, Zinani afirma que as mulheres não conseguem encontrar "na maternidade a sua autonomia, uma vez que essa função constitui uma carga [...] por colocá-la na dependência do homem em relação à proteção e à subsistência" (2013, p. 71), 


\section{$=$ TRAMA $=$}

assim, a mulher acaba por submeter-se à figura masculina restringindo-se ao ambiente doméstico, haja vista que a elas são atribuídas a educação dos filhos e o cuidado do lar, o que Ihes consome grande parte do tempo e as impossibilita de participar da esfera pública.

Reforçando o ideário de que cabe às mulheres a criação dos filhos e as tarefas domésticas, o maestro demonstra extremo contentamento com a forma de paternidade que exerce: "Era bom ver aquela garota saudável me chamando de papai e me deixando em paz, na sequência. Fui o que se pode denominar de 'pai profissional', um ausente presente. Não estava ali, mas era como se estivesse" (MELO, 2010, p. 81). O desinteresse do maestro pela filha, demonstra uma vez mais que o centro de sua vida só pode ser ocupado por ele mesmo, e pelas pessoas que também devem fazer dele o núcleo de suas vidas, confirmando o caráter egocêntrico e egoísta do narrador protagonista.

\section{CONSIDERAÇÕES FINAIS}

Ao tomarmos como parâmetro a narrativa estudada e as questões arroladas acerca da violência contra mulher, bem como os aspectos dos relacionamentos abusivos, tornar-se evidente a necessidade de um maior estudo e debate sobre tais temáticas, que não apenas permeiam a literatura, contrariamente, apresentam-se na literatura justamente por estarem inseridas na sociedade.

Valsa Negra nos mostra o passo-a-passo de um relacionamento abusivo, a partir da perspectiva masculina, que denota uma naturalização a respeito da invasão da privacidade e do controle exercido sobre a mulher/esposa. O romance também desnuda a dificuldade das mulheres em reconhecer que se encontram nesse tipo de relacionamento, acentuando a dificuldade em função do poder de manipulação e controle masculino, sempre pronto a jurar mudanças e não repetição de seus atos que em geral culminam em violência, seja ela simbólica, doméstica ou física.

O final em aberto do romance aponta para uma possibilidade de superação por parte da mulher que tenta seguir sua vida após terminar o relacionamento. O mesmo não acontece com o narrador, que insiste em seguir e procurar a ex-mulher portando arma de fogo, deixando explícito a forma como alguns homens encaram o fim do relacionamento ou a perda de um imaginado produto. A recusa em aceitar ajuda médica corrobora para que a violência aconteça, tanto que os casos de feminicídio aumentam assustadoramente no mundo todo. Daí a importância de colocar luz em questões tão primordiais como essa, objetivando desconstruir o preconceito que as acompanha.

\section{REFERÊNCIAS}

BÍBLIA SAGRADA. Tradução de Ivo Storniolo, Euclides Martins Balancin e José Luiz Gonzaga do Prado. São Paulo: Paulus, 1997. 1631 p. Velho Testamento e Novo Testamento.

BONNICI, T. Teoria e crítica literária feminista: conceitos e tendências. Maringá: Eduem, 2007.

CAMPOS, M. C. C. Gênero. In: JOBIM, José Luis (org.). Palavras da crítica. Rio de Janeiro: Imago, 1992.

DUARTE, C. L. O Cânone e a autoria feminina. Revista Tempo Brasileiro: As aporias do cânone. Rio de Janeiro, n. 129. Abril-junho de 1997, pp. 53-60.

FREYRE, G. Sobrados e Mucambos. 12. ed. Rio de Janeiro: Record, 2000.

MELO, P. Valsa negra. Rio de Janeiro: Rocco, 2010.

MURARO, R. M. A mulher no terceiro milênio. Rio de Janeiro: Rosa dos Tempos, 1995.

NASCIMENTO, E. F. do; GOMES, R.; REBELLO, L. E. F. de S. Violência é coisa de homem? A "naturalização" da violência nas falas de homens jovens. Ciênc. saúde coletiva, Rio de Janeiro, v. 14, n. 4, Ago 2009.

Disponível em: <http://www.scielo.br/scielo.php?script=sci_arttext\&pid=S1413-81232009000400021>.

Acesso em: jan. 2019.

RITT; C. F.; CAGLIARI, C. T. S; COSTA, M. M. da. Violência cometida contra a mulher compreendida como

violência de gênero. Disponível em:

<http://www.ufrgs.br/nucleomulher/arquivos/artigo_violencide\%20genero>. Acesso em: jan. 2019. 
SABADELL, A. L. Manual de Sociologia Jurídica: introdução a uma leitura externa do Direito. 3 ed. São Paulo: Revista dos Tribunais, 2005.

THERBORN, G. Sexo e poder: a família no mundo, 1900-2000. Tradução de Elisabete Dória Bilac. São Paulo: Contexto, 2006.

TIBURI, M. Feminismo em comum: para todas, todes e todos. Rio de Janeiro: Rosa dos Tempos, 2018.

ZINANI, C. J. A. Literatura e gênero: A construção da identidade feminina. 2.ed. Caxias do Sul: Editora da Universidade de Caxias do Sul, 2013.

ZOLIN, L. O. Literatura de Autoria Feminina. In: BONNICI, T; ZOLIN, L. O. (orgs.). Teoria Literária:

Abordagens históricas e tendências contemporâneas. 3. ed. Maringá: Eduem, 2009.

Recebido em 21-02-2020

Aceito em 01-04-2020 